\title{
Essential consideration of Prakriti Parikshan: Examination of body constitution
}

Available online at www.ijistweb.com

\section{REVIEW ARTICLE}

\section{Ashutosh Kumar Jain*, Smita Paul}

Rog Nidan Evam Vikriti Vigyan Department, Rani Dullaiya Smriti Ayurved P.G. College and Hospital, Bhopal, India.

*Corresponding Author's E-mail: drjain.ashutosh@gmail.com

\begin{abstract}
This article presented unique approach for selecting appropriate partner for love, business and game etc. since choosing a right person is complicated and it is very difficult when partners are unknown to each other. The article described simple and unique approach to find out right life partner considering his/her prakriti; likes, dislike, temperament and aptitude, etc.
\end{abstract}

Keywords: Ayurveda, Prakriti, Parikshan, Constitution.

\section{INTRODUCTION}

Ayurveda described prakriti parikshanas one the important method for choosing right partneralong with others like; palmistry, horoscope and numerology, etc. These all methods required some accurate information from the person being examined or questioned. Prakriti parikshan not required person's name, date of birth, time of birth and palm impression,etc. it only require the person examination in seating position in front of examiner, however photo or video of person to be examined may also employed.

Prakriti means from the beginning or original form during conception, the predominated dosa of sperm and ovam constitutes doshic features of zygote. Therefore the doshic state of paternal and maternal factors transferred to the offspring. These all may be correlated with the genetic concept of modern science which involves paternal/maternal physical and mental constitution transferred to the offspring. Acharya laghu vaghbhatt described contribution of garbhaasraya condition (uterine cavity), garbhinichesta (activity of pregnant mother), garbhiniahara (diet of pregnant mother) and ritu (time/season of conception) towards the formation of prakriti $^{\text {su.sharir.4/62 }}$.

\section{Prakriti Parikshan}

Acharya Charak presented method to investigate new things or object or to explore the knowledge of the substance based on following factors: ${ }^{\text {ch.vi.8/68 }}$

1. Kaarna: Subject

2. Karan: Object (Instrument, Medicine)

3. Karyayoni: Origin of work

4. Karya: Action

5. Karyaphala: Result of an action

6. Anubandha: Association with above

7. Desa: Area to be examined (Bhumi or Body)

8. Kala: Seasonal or Diurnal variation

9. Pravrti: Procedure to deal

10. Upaya: Application of the
procedure.

The examination of following factors are related to the examination of patient's body: ${ }^{\text {ch.vi.8/94 }}$ 
1. Ayu pramana (Age limitation of patients)

\section{Atur dosa (Patient's doshic condition)}

\section{Atur Bala (Patient's strength)}

According to acharya prakritimay be classified as follows:

\section{Vataja \\ 2. Pittaj \\ 3. Kaphaja \\ 4. Dwandaj \\ 5. Sannipataj}

The factors which are responsible for the formation of physical variation and temperamental differencesin various individual are as follows:
1. Jati (Caste)
2. Kula (Family)
3. Desha (place/state/country)
4. Kala (Era/time/period)
5. Vaya(Age of patient or individual)
6. Pratyatiniyata(Individual)

\section{Jatipraskta:}

Some features are inherited in one race/caste like Chinese \& Japanese has special facial appearances while Negroes are identified by their hyper pigmented skin color and curly hairs.

\section{Kalaprakta:}

Some features are transferred in kula like color of hair, skin tone, black / blue /grey eyes and some genetic disorders (dwarfism, auromegaly, sickle cell and thaelasamia etc.).

\section{Desaprakta:}

This depends upon aerographical environment since each and every person is affected by food habits and climatic condition of particular desa/place.

\section{Kalanupatini:}

Chakrapani described that the person who belong to krity yoja, maintain personal hygiene and kala also concern with season climate and diurnal variation which effect the dosha of the particulars.

\section{Pratyatmniyata:}

Pratyatmniyata described individual body constitution, according to charak the two individuals differs in physical and mental constitution and therefore displayed various characteristic features.

Acharya sushruta described prakriti on the basis of predominance of elementspanchamahabhuta:

\section{Nabhasa Prakriti:}

Thesepersons are religious and long lived.

2. Vayavya Prakriti, Agnaya Pakriti and Jaliya Prakriti:

These persons resemble vataj, pittaj and kaphajprakriti.

\section{Parthiva Prakriti:}

These persons involved food nourished body, good physic, social and for given essbehavior.

The human constitution also may describe according to five bhutas out of that vayu, pitta and kapha predominate bhutas already described the remaining parthiva and aakas also contributed towards body constitution. Parthiva bhutas offered firm, large body and tolerant nature while aakas bhutas offered constitution which is pure long lived and having large passages. Su.Sharir 4/79

\section{The Strength of Prakriti:}

As an insect born does not become victim of the fatal effect of the same, the types of constitution do not inflict the person.Here is in the sense of 'slightly' thus it means that the person is afflicted slightly with the symptoms caused by the constitutional dosa in comparison to other person of different constitution. su. sharir $4 / 78$

\section{Importance of Prakriti:}


1. Prakriti helps us to maintain healthy life style, which includes our diet habits and daily regimens.

2. Prakriti helps to diagnose the disease because the causative factorsof diseases and the factors of prakriti are same i.e. vataja prakriti is very much prone to vataja vikara such as; ashtigata vyadhi, vibandh and sandhigata vyadhi etc. The similar concept also applied on pittaja \& kaphaj prakriti.

\section{Prakriti towards Health Regimen:}

1. Prakriti define physical or mental constitution of body.

2. Prakriti suggested us ahar and vihar for our temperament.

3. Prakriti suggested possibility or types of diseases for one should be more careful.

Table 1: Characteristics features which depend upon Prakriti

\begin{tabular}{|c|c|c|c|c|}
\hline Sr.No. & Factors & Vataj & Pittaja & Kaphaja \\
\hline 1 & Skin & Cracked,dusky & $\begin{array}{l}\text { Wrinkles,blue } \\
\text { patches in skin }\end{array}$ & Nourished well \\
\hline 2 & Hair \& Nail & Scanty, rough & $\begin{array}{l}\text { Brown copper } \\
\text { coloured, scanty } \\
\text { hairs \&baldness }\end{array}$ & Thick and black shiny hair \\
\hline 3 & $\begin{array}{c}\text { Body } \\
\text { Constitution }\end{array}$ & Tall and thin & Medium & $\begin{array}{l}\text { Excellent compact \&well } \\
\text { nourished }\end{array}$ \\
\hline 4 & Veins & Prominent & Medium & $\begin{array}{l}\text { Excellent compact \&well } \\
\text { nourished }\end{array}$ \\
\hline 5 & Activity & $\begin{array}{l}\text { Unsteadiness very } \\
\text { talkative,irritable }\end{array}$ & $\begin{array}{l}\text { Defeats other in } \\
\text { talk }\end{array}$ & $\begin{array}{c}\text { Dull incitation with less } \\
\text { activities }\end{array}$ \\
\hline 6 & Movements & $\begin{array}{l}\text { Unstable joints- } \\
\text { eyes-eyebrows- } \\
\text { jaws-lips-tongue- } \\
\text { head-shoulder- } \\
\text { hand-legs. }\end{array}$ & Medium & Less \\
\hline 7 & Joints & Cracking sound & - & Unctuous well knee joint \\
\hline 8 & Eyes & $\begin{array}{l}\text { Rough,lustreless } \\
\text { unpleasant,lid } \\
\text { keeps open while } \\
\text { sleeping }\end{array}$ & $\begin{array}{l}\text { Eyes are yellow or } \\
\text { red feeling warm }\end{array}$ & $\begin{array}{c}\text { Eyes are red in } \\
\text { angles,wide,well } \\
\text { definedand more eye } \\
\text { lashes }\end{array}$ \\
\hline 9 & $\begin{array}{l}\text { Koshta } \\
\text { (digestive } \\
\text { power) }\end{array}$ & Constipated & Moderate & Mridu \\
\hline 10 & Strength & Little & Moderate & More \\
\hline 11 & Voice & $\begin{array}{l}\text { Obstructed, } \\
\text { interacted,harsh,bro } \\
\text { ken, } \\
\text { dry }\end{array}$ & Medium & Clear,high pitch,melodious \\
\hline 12 & Sweat & Mild & $\begin{array}{c}\text { Perspire } \\
\text { heavily,emits bad } \\
\text { smell from the } \\
\text { body }\end{array}$ & Medium \\
\hline 13 & Sleep & $\begin{array}{l}\text { Little, } \\
\text { Disturbed }\end{array}$ & Medium & Not much trouble by sleep \\
\hline 14 & $\begin{array}{l}\text { Thirst \& } \\
\text { anger }\end{array}$ & Irrespective & Excellent & Moderatethrust \& anger \\
\hline 15 & Likes & Music, humor, & Sweet,astringent,bi & Hot,dry \\
\hline
\end{tabular}




\begin{tabular}{|c|c|c|c|c|}
\hline & & $\begin{array}{l}\text { hunting, gambling, } \\
\text { desire to sweet- } \\
\text { sour-salty and hot } \\
\text { foods,eat light food }\end{array}$ & tter and cold foods. & $\begin{array}{l}\text { fruits, bitter,astringent and } \\
\text { pungent. }\end{array}$ \\
\hline 16 & Dislike & Cold thing & Sun light,hot thing & $\begin{array}{c}\text { More quantity of food,cold } \\
\text { thing }\end{array}$ \\
\hline 17 & $\begin{array}{l}\text { Wealth and } \\
\text { life span }\end{array}$ & Little & Medium & Excellent \\
\hline 18 & Nature & Cruel,ungrateful. & $\begin{array}{l}\text { Always in trouble, } \\
\text { becomes anger, } \\
\text { intelligent, } \\
\text { clever, brilliant }\end{array}$ & $\begin{array}{l}\text { Intelligent,good manner, } \\
\text { right attitude, peaceful, } \\
\text { energetic, do not speak } \\
\text { hard and abusive words }\end{array}$ \\
\hline 19 & Dreams & $\begin{array}{l}\text { Moves in the } \\
\text { sky,roaming in the } \\
\text { mountain,welling } \\
\text { on tree }\end{array}$ & $\begin{array}{l}\text { See the red colored } \\
\text { flowers like palash, } \\
\text { fire, lighting and } \\
\text { sunray. }\end{array}$ & $\begin{array}{c}\text { Sea water, reservoir with } \\
\text { full of water,lotus,birds } \\
\text { and } \\
\text { clouds }\end{array}$ \\
\hline 20 & Sexual life & $\begin{array}{l}\text { Cannot control } \\
\text { there felling,not } \\
\text { liked by women, } \\
\text { not having many } \\
\text { children. }\end{array}$ & $\begin{array}{l}\text { Insufficiency of } \\
\text { semen, sexual } \\
\text { desire, don't like } \\
\text { by women }\end{array}$ & $\begin{array}{l}\text { Excessive desire (due to } \\
\text { abundant sukra),will be } \\
\text { having more children }\end{array}$ \\
\hline
\end{tabular}

\section{ACKNOWLEDGEMENT}

The authors are thankful to IJIST Journal for publishing their article.

\section{CONFLICTS OF INTEREST}

The author declares that there are no conflicts of interest.

\section{REFERENCES}

1. Basic principles of Kriya Sharir by $\mathrm{dr}$ Srikanta kumar Panda - Chaukhambha Orientalia, Delhi, 2006 edition.

2. Prakriti At A Glance by Dr sandeep Shah Chaukambha Sansrit Sansthan Varanasi ,2010 edition

3. Sushrut Samhita Dalhna Tika, edited by Achaya yadav ji trivikram ji and narayan ram acharya, published by chukambha sur bharti prakashan Varanasi, edition 2017.

4. Charak samhita, Chakrapani tika, Edited by Achaya yadav ji trivikram ji, published by chukambha sur bharti prakashan Varanasi, edition 2016.

5. Asthang hridya, Arundatta and Hemadri Tikka, Edited by Pt. Hari Sadashiv Shastri, Paradakara, published by chukambha sur bharti prakashan Varanasi, edition 2016

6. Parameswarappa's ayurvediya Vikriti Vigyan and Rog Vigyan Volume 1,
By Dr. P.S. Byadgi, Published By Chaukambhha Publication New Delhi, 2016.

7. A text Book Of Rog Vigyan And Vikriti Vigyan By Rekha N. Jain and Dr Nandkumar Y. thite. Published Chaukambha Pratisthan Delhi, 2007

8. Clinical Dignose of ayurveda by prof.Dr. M. Srinivasulu, published by Chaukambha Sanskrit pratisthan, Delhi,2011. 